\title{
Oestradiol in follicular fluid and in utero-ovarian venous and peripheral plasma during parturition and post- partum oestrus in the tammar, Macropus eugenii
}

\author{
J. D. Harder*, L. A. Hinds, C. A. Horn and C. H. Tyndale-Biscoe \\ Division of Wildlife \& Rangelands Research, CSIRO, P.O. Box 84, Lyneham, A.C.T. 2602, \\ Australia, and ${ }^{*}$ Department of Zoology, The Ohio State University, Columbus, Ohio 43210-1293, \\ U.S.A.
}

\begin{abstract}
Summary. Oestradiol-17 $\beta$ was measured in plasma and follicular fluid by a radioimmunoassay validated for the tammar. Plasma was sampled from the peripheral circulation and both utero-ovarian veins to assess the contribution of oestradiol from the corpus luteum in one ovary and from the Graafian follicle in the other during late pregnancy, parturition, post-partum oestrus and ovulation. Concentrations of oestradiol in the peripheral plasma and in the vein draining the CL remained $<5 \mathrm{pg} / \mathrm{ml}$ on all days except the day of parturition, when they were $12.7 \mathrm{pg} / \mathrm{ml}$ and $14.3 \mathrm{pg} / \mathrm{ml}$ respectively. Mean oestradiol concentration in the vein draining the Graafian follicle was significantly higher than the mean peripheral concentration on Days 24-27. The highest average concentration $(36.5 \mathrm{pg} / \mathrm{ml})$ occurred on Day 27 coincident with parturition and before oestrus. These latter concentrations were significantly correlated with the concentration and total oestradiol in the fluid of the preovulatory Graafian follicle ( $r=0.73$ and $r=0.82$ respectively), thus providing strong evidence that the Graafian follicle is the main source of oestradiol in the peripheral circulation at this time.
\end{abstract}

\section{Introduction}

The tammar, Macropus eugenii, is a monovular, polyoestrous marsupial in which gestation is less than 1 day shorter than the oestrous cycle. Post-partum oestrus generally occurs $8 \mathrm{~h}$ after birth of the single young (Tyndale-Biscoe, Hinds, Horn \& Jenkin, 1983), and ovulation occurs about $30 \mathrm{~h}$ later from the ovary opposite that bearing the corpus luteum $(\mathrm{CL})$ of pregnancy (Evans, Tyndale-Biscoe \& Sutherland, 1980). Changes in the concentration of progesterone in the CL (Young \& Renfree, 1979 ) and peripheral plasma during the peri-partum period have been reported (Hinds \& TyndaleBiscoe, 1982; Tyndale-Biscoe et al., 1983) and it is clearly established that the CL is the main source of progesterone (Findlay, Ward \& Renfree, 1983). Less is known about oestrogen during this period in the tammar or other marsupials. Harder \& Fleming (1981) measured highest levels of oestradiol$17 \beta$ in the peripheral plasma of the opossum, Didelphis virginiana, during pro-oestrus, and Flint $\&$ Renfree (1982) found peak levels of $16 \mathrm{pg}$ oestradiol- $17 \beta / \mathrm{ml}$ in plasma of tammars shot on Kangaroo Island during the peri-partum period, compared to levels of $5-10 \mathrm{pg} / \mathrm{ml}$ during earlier phases of gestation. Shaw \& Renfree (1984) confirmed these levels in captive tammars bled sequentially during the peri-partum period. They also detected a transient pulse of oestradiol at Day 5 of pregnancy coincident with the pulse of progesterone that occurs on Day 5 or 6 (Hinds \& Tyndale-Biscoe, 1982). The CL may be the source of the early pulse of oestradiol, given that Renfree, Flint, Green \& Heap (1984) detected it in quiescent CL. However, Renfree et al. (1984) and Shaw \& Renfree (1984) found negligible quantities of oestradiol in CL of late pregnancy, and so 
the $\mathrm{CL}$ is unlikely to be the source of the peri-partum rise in peripheral plasma oestradiol concentrations. Because the single ovulation occurs from alternate ovaries in the tammar, the separate contributions of the CL and Graafian follicle to peripheral levels of oestradiol and other hormones can be examined by sampling the venous effluent from each side. In this paper we report the concentrations of oestradiol-17 $\beta$ in follicular fluid and in peripheral and utero-ovarian venous plasma from tammars sampled on successive days of late pregnancy, parturition and post-partum oestrus and ovulation.

\section{Materials and Methods}

\section{Animals and experimental design}

The tammars were from a breeding colony established with animals brought from Kangaroo Island, South Australia in 1974. They were maintained in grassy outdoor pens; water and pelleted lucerne and oats were available ad libitum. All females were adults of $>2$ years of age and weighed $4.4 \pm 0.1 \mathrm{~kg}$. Three series of tammars were selected from the breeding colony in February. All were carrying small pouch young and were presumed to be pregnant. Pouch young were removed (Day 0 ) to reactivate the quiescent $C L$ and the diapausing blastocyst. Series I consisted of 11 females from which the ovary bearing the Graafian follicle was removed on Day 23 of pregnancy. A peripheral blood sample was taken from a caudal vein and the ovaries were stored frozen. In Series II, 5 of 23 females were chosen at random for laparotomy on each of Days 24, 25 and 26, 6 on Day 27 and 1 each on Days 28 and 29 after removal of pouch young. They were anaesthetized with sodium thiamylal (Surital : Parke-Davis, Caringbah, NSW, Australia). Blood (20 ml) was collected with an 18-gauge needle and heparinized syringe from both utero-ovarian veins, one draining the ovary with the $\mathrm{CL}$ of pregnancy and the other draining the ovary with the large preovulatory follicle or newly formed CL of post-partum ovulation. Peripheral blood $(20 \mathrm{ml})$ was also taken by cardiac puncture, and the anaesthetized animals were then killed by an overdose of sodium thiamylal. In Series III, females were selected for another experiment designed to examine the role of the CL at parturition, and some of the material from the control animals only has been used in this study. Five pregnant females had the ovary without the CL removed on Day 17 and these were killed on Day 28. Five other pregnant females were laparotomized on Day 23, left intact and killed on Day 29. Both groups were examined each day after laparotomy for births and were treated at autopsy in the same way as those in Series II. In the Day-17 group, only the utero-ovarian vein draining the remaining ovary was sampled and in all these females it now contained both a CL of pregnancy and a Graafian follicle or $\mathrm{CL}$ of post-partum ovulation.

Plasma was separated and aliquants were stored at $-15^{\circ} \mathrm{C}$ for subsequent assay of oestradiol and other hormones. From females of Series II and III the urogenital tract was dissected out, the corpora lutea and Graafian follicles separated, weighed and frozen and the uterine contents examined for embryos or newly ovulated eggs. Follicular fluid was obtained from the frozen ovaries maintained on solid $\mathrm{CO}_{2}$. After the surface of the frozen Graafian follicle (3-5 mm diameter) was partly thawed by contact with a finger, cut and reflected, the frozen ball of follicular fluid was removed and placed in a small tapered vial and weighed.

\section{Assay of oestradiol-17 $\beta$}

Duplicate $0.5 \mathrm{ml}$ plasma samples were diluted with $0.5 \mathrm{ml}$ distilled water in glass-stoppered Quickfit tubes and held in a waterbath at $85^{\circ} \mathrm{C}$ for $3 \mathrm{~min}$. Samples were treated in this manner to denature protein in female tammar plasma that binds oestradiol with high affinity (Shaw \& Renfree, 1984). Unless this was done recovery of $\left[{ }^{3} \mathrm{H}\right]$ oestradiol was low and inconsistent $(10-60 \%)$.

Included in each extraction were duplicate $0.5 \mathrm{ml}$ samples of assay buffer, tammar plasma treated with charcoal $(50 \mathrm{mg} / \mathrm{ml})$ to remove steroids, plasma from ovariectomized-adrenalecto- 
mized tammars, plasma with added oestradiol (2.5-100 pg; Sigma Chemical Co, St Louis, MO, U.S.A.), and plasma pooled from the unknown samples containing 30000 c.p.m. $\left[{ }^{3} \mathrm{H}\right]$ oestradiol$17 \beta$ for correction of procedural losses. Extraction was accomplished with $15 \mathrm{~min}$ of vigorous machine shaking of the cooled samples with $4 \mathrm{ml}$ peroxide-free diethyl ether. After centrifugation, the extraction tubes were immersed in a solid $\mathrm{CO}_{2}$-ethanol bath to snap freeze the plasma. The ether layer was then poured directly into assay tubes $(12 \times 175 \mathrm{~mm}$, glass $)$ and dried under $\mathrm{N}_{2}$.

The radioimmunoassay was adapted from those of Powell \& Stevens (1973) and Butcher, Collins \& Fugo (1974). The antiserum to oestradiol-17 $\beta$, provided by Dr R. I. Cox, Hormone Assay Group, CSIRO, Prospect, New South Wales, was raised against oestradiol-17 $\beta-6-C M O-B S A$ in sheep (lot 6181). It was highly specific; cross-reactivity relative to oestradiol- $17 \beta$ was $1 \%$ for oestrone, oestradiol- $17 \alpha$ and oestriol, and $<0.1 \%$ for testosterone, androstenedione, progesterone, $17 \alpha$-hydroxyprogesterone and cortisol. The antisera, diluted 1:80000, bound $50 \%$ of $15 \mathrm{pg}$ $\left[2,4,6,7,16,17-{ }^{3} \mathrm{H}\right]$ oestradiol-17 (sp. act. $140 \mathrm{Ci} / \mathrm{mmol}$ : Amersham International Ltd, Bucks, U.K.) used in the assay. Duplicates of standard solutions containing $0,1,2 \cdot 5,5,10,25,50,100$ and $250 \mathrm{pg}$ oestradiol-17 $\beta$ in $0.2 \mathrm{ml}$ assay buffer $\left(0.1 \mathrm{M}\right.$-phosphate-buffered saline containing $0.1 \% \mathrm{NaN}_{3}$ and $0.1 \%$ gelatine, $\mathrm{pH} 7.2$ ) were included in each assay. Dried extracts were redissolved in $0.2 \mathrm{ml}$ assay buffer. Antisera (1:80 000) and $15 \mathrm{pg}\left[{ }^{3} \mathrm{H}\right]$ oestradiol-17 $\beta$, each in $0 \cdot 1 \mathrm{ml}$ assay buffer, were added to each tube and mixed thoroughly. The assay tubes were held at $35^{\circ} \mathrm{C}$ for $5 \mathrm{~min}$ before being transferred to an ice-water bath for a $4-\mathrm{h}$ incubation at $4^{\circ} \mathrm{C}$. Free and bound steroids were separated by mixing with $0.4 \mathrm{ml}$ cold dextran-coated charcoal suspension $(0.625 \%$ Norit A and $0.0625 \%$ Dextran T-70). The tubes were held at $4^{\circ} \mathrm{C}$ for $20 \mathrm{~min}$ and then centrifuged at $800 \mathrm{~g}$ for $15 \mathrm{~min}$ at $4^{\circ} \mathrm{C}$. The supernatant was decanted into $10 \mathrm{ml}$ scintillation fluid $(42 \mathrm{ml}$ Liquifluor and $150 \mathrm{ml}$ dioxan in 1 litre toluene), mixed thoroughly and allowed to stand for $4 \mathrm{~h}$ before the radioactivity in the samples was recorded on a scintillation spectrometer. Oestradiol values were calculated with logit transformation and the weighted linear regression analysis of Rodbard, Bridson \& Rayford (1969). Regression analyses and Student's $t$ tests were calculated according to Steel \& Torrie (1960). All means are presented \pm 1 standard error of the mean (s.e.m.).

\section{Validation of assay}

The sensitivity of the assay was $2.5 \mathrm{pg} / \mathrm{ml}$, i.e. the smallest amount of measurable steroid that was significantly different $(P<0.05)$ from zero. Extracts of $0.5 \mathrm{ml}$ plasma from adrenalectomizedovariectomized tammars and charcoal-treated plasma, included in each assay to estimate the solvent and plasma blank, averaged $7 \cdot 5 \pm 0.4$ and $6.2 \pm 0.3$ pg per tube respectively, in 16 assays. The mean recovery of $\left[{ }^{3} \mathrm{H}\right]$ oestradiol- $17 \bar{\beta}$, equilibrated with plasma oestrogens before extraction, was $81.6 \pm 1.0 \%(n=102)$. Calculation of oestradiol in samples involved subtraction of the plasma blank for adrenalectomized-ovariectomized tammars and correction for procedural losses. An interassay coefficient of variation of $15 \cdot 3 \%$ was determined from repeated measurements of the same plasma pool $(28.6 \pm 1.4 \mathrm{pg} / \mathrm{ml})$ in 10 assays. Intra-assay coefficient of variation was $3 \%$ at $12.8 \mathrm{pg} / \mathrm{ml}(n=8)$ and averaged $4.2 \%$ for duplicate determinations of plasma samples in routine assays $(n=17)$.

During development of the assay, oestrogens in ether extracts were partly purified and separated on columns of Sephadex LH-20 with a methylene chloride : methanol $(95: 5, \mathrm{v} / \mathrm{v})$ solvent according to the method of Butcher et al. (1974). Chromatography was omitted in routine assays.

The suitability of ether extracts for direct assay was assessed by comparison of assay values obtained for oestradiol-17ß purified and separated on Sephadex LH-20 columns with those for oestradiol in the same peripheral and utero-ovarian venous samples $(n=14)$ but measured directly from the extract. Concentrations estimated by the two methods were very similar and highly correlated $(y=0.04+1.04 x, r=0.98)$. The average ratio of oestradiol concentrations measured in chromatographed extracts to those measured without chromatography was 0.98 . To assess parallelism between sample and standard curves, $0.5,0.4,0.25$ and $0.1 \mathrm{ml}$ samples of a late 
pregnancy plasma pool were diluted and assayed in duplicate. The regression equation was $y=$ $3.24-2.50 x(r=0.99)$ for the standard curve and $y=6.10-2.48 x(r=0.99)$ for plasma dilutions. The accuracy of the assay was demonstrated by comparison of amounts of oestradiol $17 \beta$ added $(2 \cdot 5,5,10,25,50$ and $100 \mathrm{pg})$ to $0.5 \mathrm{ml}$ blank plasma before heat treatment and extraction with those measured $(2 \cdot 2,4 \cdot 2,8 \cdot 4,21 \cdot 6,43 \cdot 8$ and $81 \cdot 8 \mathrm{pg}$, respectively). Each amount was measured in at least 7 assays; quantitative recovery $(82-88 \%$, mean $=85.3 \%$ ) was slightly higher than recovery estimated with $\left[{ }^{3} \mathrm{H}\right]$ oestradiol $-17 \beta(81.6 \%)$.

\section{Results}

Of the 26 tammars selected for the experiment on Days 23 to $26,6(23 \%$ ) were not pregnant (Table 1 ), which is the usual frequency (Renfree \& Tyndale-Biscoe, 1973). Unfortunately, 4 of these animals were selected by chance on Day 26, which is the expected day of parturition (Merchant, 1979). The remainder of those examined on Days 23-26 and 1 on Day 27 were in advanced stages of pregnancy, and none had yet ovulated. The rest of those examined on Days 27-29 had a neonate in the pouch. Of the 10 females examined daily until Day 28 or 29,3 gave birth on Day 26,4 on Day 27 and 3 on Day 28. Three females examined on Day 27 and all but one of those on Days 28 and 29 had mated, while 2 females had ovulated by Day 28 and 4 by Day 29. This is the normal sequence of birth, mating and ovulation in tammars as reported by Tyndale-Biscoe \& Rodger (1978), Evans et al. (1980) and Tyndale-Biscoe et al. (1983).

Concentrations of oestradiol-17 $\beta$ in peripheral plasma of tammars sampled on all days except Days 27 and 28 averaged less than $5 \mathrm{pg} / \mathrm{ml}$ and did not exceed $9 \mathrm{pg} / \mathrm{ml}$ in any sample (Text-fig. 1). However, females sampled on Day 27 had significantly elevated concentrations of $12 \cdot 7 \pm 3 \cdot 3 \mathrm{pg} / \mathrm{ml}$ $(P<0.05)$. Oestradiol levels in utero-ovarian venous plasma from the ovary with the CL were similar to those in peripheral plasma in pregnant and post-partum females, including elevated concentrations on Day 27 (Text-fig. 1).

By contrast, the mean oestradiol concentration $(26.6 \pm 6.5 \mathrm{pg} / \mathrm{ml})$ in utero-ovarian venous plasma from the ovary with the follicle, collected on Days 24- 27 was significantly higher $(P<0.05)$ than that $(6.8 \pm 1.8 \mathrm{pg} / \mathrm{ml})$ from the CL side. This comparison was not possible on Day 28 , and on Day 29 the difference was not significant (Text-fig. 1). The highest mean concentration occurred on Day 27 but the large variances reflect the fact that only some animals had concentrations $>10$ $\mathrm{pg} / \mathrm{ml}$ on each day (Table 1 ). This might indicate that secretion of oestradiol from the ovary bearing the follicle is only transiently elevated and that the elevation might be closely related to the time of parturition. The highest concentration $(104 \mathrm{pg} / \mathrm{ml})$ was observed in an animal sampled

Table 1. Summary of observations on all tammars sampled or dissected on successive days after initiating the reproductive cycle by removing the pouch young (RPY)

\begin{tabular}{lccccccc}
\hline & \multicolumn{7}{c}{ Days after RPY } \\
\cline { 2 - 8 } & 23 & 24 & 25 & 26 & 27 & 28 & 29 \\
\hline $\begin{array}{l}\text { No. of animals } \\
\text { No. of animals }\end{array}$ & 11 & 5 & 5 & 5 & 6 & 6 & 6 \\
$\quad \begin{array}{l}\text { Pregnant } \\
\text { Post partum }\end{array}$ & 11 & 4 & 4 & 1 & 1 & 0 & 0 \\
$\quad$ Mated & 0 & 0 & 0 & 0 & 5 & 6 & 5 \\
$\quad \begin{array}{l}\text { Ovulated } \\
\text { Oestradiol > 10 pg/ml }\end{array} \quad-\quad 0$ & 0 & 0 & 0 & 0 & 6 & 5 \\
$\quad$ in utero-ovarian vein \\
of follicle-bearing ovary
\end{tabular}




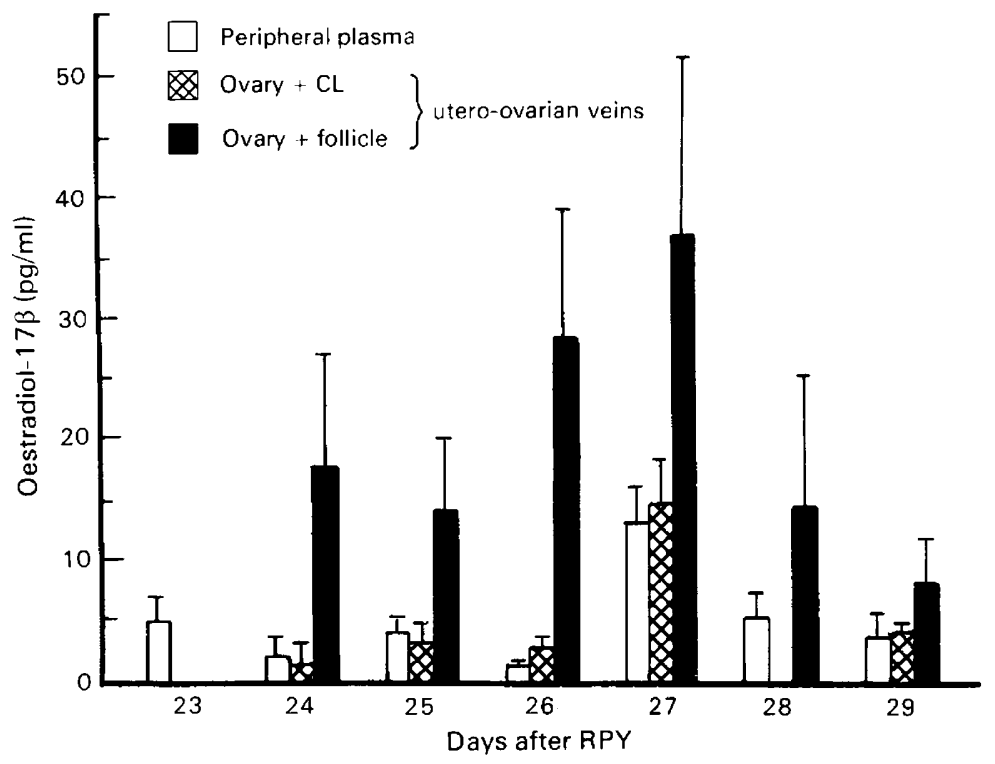

Text-fig. 1. Oestradiol-17 concentrations in peripheral plasma, and in plasma taken from the utero-ovarian veins draining the ovary with the corpus luteum and the ovary with the Graafian follicle on Days 23 to 29 after removing the pouch young (RPY). Values are mean \pm s.e.m.; for numbers and condition of the tammars used for each day's samples see Table 1 . In animals examined on Day 28 the ovary without the CL had been removed on Day 17 and blood was not assayed from the corresponding utero-ovarian vein.

immediately post partum when both uteri were still contracting. Lower values $(33.8 \mathrm{pg} / \mathrm{ml})$ were measured in plasma of another animal collected $<6 \mathrm{~h}$ after birth and still lower $(8.8 \mathrm{pg} / \mathrm{ml})$ in another sampled 12-18 h after parturition.

Ovaries were collected immediately after the utero-ovarian venous samples were taken, and it was therefore possible to examine the preovulatory follicle as the source of oestradiol. Follicular diameter increased from $2.9 \mathrm{~mm}$ on Day 23 to $4.3 \mathrm{~mm}$ on Day 27 (Table 2) and $4.1 \mathrm{~mm}$ for the remaining follicles on Days 28 and 29; follicular diameter and the weight of follicular fluid were significantly correlated $(r=0 \cdot 84)$. The concentrations of oestradiol in follicular fluid showed only modest increases from Day 23 to 27 , but the total content of oestradiol in the Graafian follicles

Table 2. Size and oestradiol-17 $\beta$ content (mean \pm s.e.m.) of preovulatory follicles collected from tammars 23-27 days after removal of pouch young (RPY)

\begin{tabular}{|c|c|c|c|c|c|}
\hline \multirow{2}{*}{$\begin{array}{l}\text { Day } \\
\text { after } \\
\text { RPY }\end{array}$} & \multirow{2}{*}{$\begin{array}{c}\text { Sample } \\
\text { size } \\
(n)\end{array}$} & \multirow{2}{*}{$\begin{array}{l}\text { Diam. } \\
\text { of } \\
\text { follicle } \\
(\mathrm{mm})\end{array}$} & \multicolumn{3}{|c|}{ Follicular fluid } \\
\hline & & & $\begin{array}{l}\mathrm{Wt} \\
(\mathrm{mg})\end{array}$ & $\begin{array}{l}\text { Oestradiol-17 } \\
\text { content }(\mathrm{pg})\end{array}$ & $\begin{array}{l}\text { Oestradiol-17及 } \\
\text { conc. }(\mathrm{ng} / \mathrm{ml})^{*}\end{array}$ \\
\hline 23 & 11 & $2.9 \pm 0.2$ & $6 \pm 0.9$ & $235 \pm 70$ & $37 \pm 11$ \\
\hline 24 & 4 & $3.3 \pm 0.2$ & $4 \pm 0.8$ & $198 \pm 88$ & $57 \pm 21$ \\
\hline 25 & 5 & $3.5 \pm 0.1$ & $10 \pm 0.9$ & $605 \pm 167$ & $64 \pm 19$ \\
\hline 26 & 5 & $3.7 \pm 0.2$ & $13 \pm 0.4$ & $470 \pm 263$ & $39 \pm 20$ \\
\hline 27 & 5 & $4 \cdot 3 \pm 0 \cdot 3$ & $20 \pm 3.8$ & $1229 \pm 598$ & $66 \pm 23$ \\
\hline
\end{tabular}

* Volume obtained from fluid weight: $1 \mathrm{mg}=1 \mu \mathrm{l}$. 


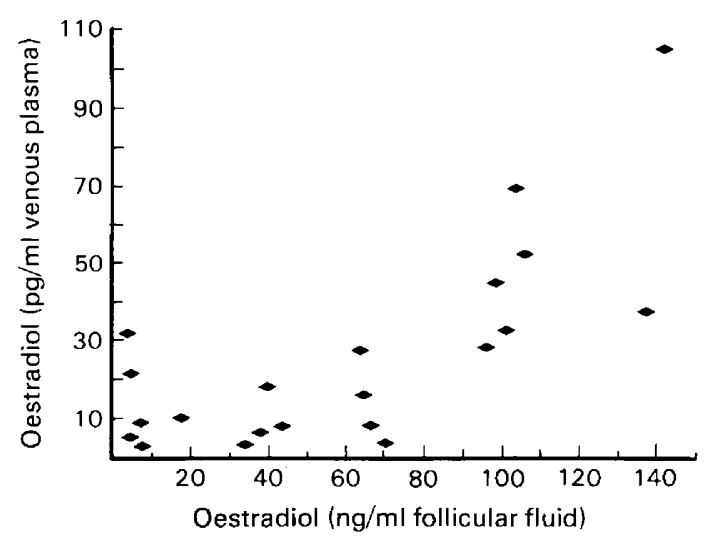

Text-fig. 2. Relationship of oestradiol-17 $\beta$ concentrations in follicular fluid and in plasma collected from the utero-ovarian vein draining the ovary with the Graafian follicle on Days 2427 after removing the pouch young.

increased markedly from $235 \mathrm{pg}$ on Day 23 to $1229 \mathrm{pg}$ on Day 27 . These were closely correlated $(y=8.91+0.023 x, r=0.82)$ with oestradiol concentrations in the corresponding utero-ovarian venous plasma samples of the tammars. Furthermore, the concentrations of oestradiol in individual follicles were signficantly correlated $(r=0.73)$ with a $\log$ transformation of the oestradiol level in the corresponding utero-ovarian venous plasma (Text-fig. 2).

\section{Discussion}

The pattern of oestradiol in peripheral plasma seen in our tammars, with a transient rise to $12 \cdot 7$ $\mathrm{pg} / \mathrm{ml}$ immediately after parturition, was very similar to the pattern in wild tammars on Kangaroo Island, in which the values in animals shot near the time of parturition were $15-20 \mathrm{pg} / \mathrm{ml}$ (Flint \& Renfree, 1982). Shaw \& Renfree (1984) followed the changes in oestradiol and progesterone in peripheral plasma through the peri-partum period and concluded that the rise in oestradiol was not associated with parturition but only with oestrus. Our study did not provide timed, serial samples, but the peak in peripheral oestrogen and that from the utero-ovarian vein occurred on Day 27, coincident with parturition, and had declined a day later when most females mated. This was similar to the American opossum (Didelphis virginiana) in which peripheral levels of oestradiol reached a peak of $23 \mathrm{pg} / \mathrm{ml} 2$ days before oestrus and then dropped to $9 \mathrm{pg} / \mathrm{ml}$ at oestrus (Harder \& Fleming, 1981). In a previous study (Tyndale-Biscoe et al., 1983) progesterone was shown to decline precipitately at parturition, and it was suggested that the onset of post-partum oestrus might be initiated as a result of a change in the ratio of progesterone to oestrogen. In the present studies progesterone from the ovary bearing the CL declined from $3 \mathrm{ng} / \mathrm{ml}$ on Day 26 to $<1 \mathrm{ng} / \mathrm{ml}$ on Day 27 (L. A. Hinds \& C. H. Tyndale-Biscoe, unpublished results), which would support this suggestion which is known to apply to certain other mammals (Liggins, 1982).

The only study of oestradiol in peripheral plasma of another species of macropodid marsupial is that of Walker \& Gemmell (1983). They reported much higher oestradiol levels $(57-266 \mathrm{pg} / \mathrm{ml})$ in pregnant and parturient Tasmanian Bennett's wallabies (Macropus rufogriseus rufogriseus), but they did not detect any changes in oestradiol concentrations in serial blood samples collected throughout the time of parturition.

Our results clearly show that the major source of circulating oestradiol-17 $\beta$ in the tammar is the ovary with the large preovulatory follicle. Concentrations in the utero-ovarian vein draining the 
follicle ovary were 3-10 times above those in plasma from the contralateral vein or the peripheral circulation $(P<0 \cdot 05)$. For comparison, the average ovarian vein concentration of oestradiol $(66 \cdot 8$ $\mathrm{pg} / \mathrm{ml}$ ) during the oestrous cycle of Finn ewes was 22-56 times that of peripheral concentrations (Scaramuzzi \& Land, 1978) and in women during the late follicular phase of the menstrual cycle it was approximately 25 times higher than that in the peripheral circulation (Peters \& McNatty, 1980). The lower ratio in tammars is understandable because ovarian venous secretions in the utero-ovarian vein are diluted with plasma from the non-pregnant uterus.

The average concentration of oestradiol-17 $\beta$ in follicular fluid of ovaries collected from postpartum tammars just before ovulation $(66 \mathrm{ng} / \mathrm{ml})$ was much lower than that $(1570 \mathrm{ng} / \mathrm{ml})$ in large follicles collected during the late follicular phase of the menstrual cycle of women (McNatty et al., 1976) but similar to the range of $20-300 \mathrm{ng} / \mathrm{ml}$ measured in sheep follicular fluid (McNatty, Dobson, Gibb, Kieboom \& Thurley, 1981). The ratio of oestradiol concentration in peripheral plasma to that in follicular fluid ranged from $1: 5000$ to $1: 27000$ in tammars, similar to ratios calculated from published values for ewes (Scaramuzzi \& Land, 1978; McNatty et al., 1981) and women (Peters \& McNatty, 1980).

The correlation of oestradiol concentration in follicular fluid and utero-ovarian venous plasma provides additional evidence that the preovulatory follicle is the major secretory source of oestradiol during late gestation and pro-oestrus. Increases in utero-ovarian venous concentrations were exponential relative to follicular fluid concentrations. This necessitated logarithmic transformation of the former for linear regressional analysis. The highest oestradiol concentrations $(35 \mathrm{pg} / \mathrm{ml})$ in the utero-ovarian venous plasma were associated with follicular fluid concentrations $>100 \mathrm{ng} / \mathrm{ml}$. This could mean either that high levels of oestradiol in the utero-ovarian vein are dependent on high levels in the follicle or that high levels in the follicular fluid only reflect high secretion rates into the ovarian vein. The latter is perhaps more likely. McNatty et al. (1981) concluded that $>90 \%$ of the oestradiol produced by large follicles in ewes entered the blood stream without first accumulating in follicular fluid.

The work reported here was done while J.D.H. was a Visiting Scientist with CSIRO in Canberra. Financial assistance for the visit was provided by The Ohio State University, CSIRO and the National Science Foundation, Washington, D.C., under the U.S.-Australian Bilateral Science Agreement. We thank Dr Ron Cox (CSIRO, Sydney) for the oestradiol antiserum and Ray Leckie and John Wright for technical assistance.

\section{References}

Butcher, R.L., Collins, W.E. \& Fugo, N.W. (1974) Plasma concentration of $\mathbf{L H}, \mathbf{F S H}$, prolactin, progesterone and estradiol-17 $\beta$ throughout the 4-day estrous cycle of the rat. Endocrinology 94, 1704-1708.

Evans, S.M., Tyndale-Biscoe, C.H. \& Sutherland, R.L. (1980) Control of gonadotrophin secretion in the female tammar wallaby (Macropus eugenii). J. Endocr. 86, 13-23.

Findlay, L., Ward, K.L. \& Renfree, M.B. (1983) Mammary gland lactose, plasma progesterone and lactogenesis in the marsupial Macropus eugenii. $J$. Endocr. 97, 425-436.

Flint, A.P.F. \& Renfree, M.B. (1982) Oestradiol-17ß in the blood during seasonal reactivation of the diapausing blastocyst in a wild population of tammar wallabies. $J$. Endocr. 95, 293-300.

Harder, J.D. \& Fleming, M.W. (1981) Estradiol and progesterone profiles indicate a lack of endocrine recognition of pregnancy in the opossum. Science, N.Y. 212, 1400-1402.
Hinds, L.A. \& Tyndale-Biscoe, C.H. (1982) Plasma progesterone levels in the pregnant and non-pregnant tammar, Macropus eugenii. J. Endocr. 93, 99-107.

Liggins, G.C. (1982) The fetus and birth. In Embryonic and Fetal Development, pp. 114-141. Eds C. R. Austin \& R. V. Short. Cambridge University Press.

McNatty, K.P., Baird, D.T., Bolton, A., Chambers, P., Corker, C.S. \& McLean, H. (1976) Concentration of oestrogens and androgens in human ovarian venous plasma and follicular fluid throughout the menstrual cycle. $J$. Endocr. 71, 77-85.

MeNatty, K.P., Dobson, C., Gibb, M., Kieboom, L. \& Thurley, D.C. (1981) Accumulation of luteinizing hormone, oestradiol and androstenedione by sheep ovarian follicles in vivo. J. Endocr. 91, 99-109.

Merchant, J.C. (1979) The effect of pregnancy on the interval between one oestrus and the next in the tammar wallaby, Macropus eugenii. J. Reprod. Fert. 56, 459-463.

Peters, H. \& McNatty, K.P. (1980) The Ovary: a 
Correlation of Structure and Function in Mammals. University of California Press, Los Angeles.

Powell, J.E. \& Stevens, V.C. (1973) Simple radioimmunoassay of five unconjugated ovarian steroids in a single sample of serum or plasma. Clin. Chem. 19, 210-215.

Renfree, M.B. \& Tyndale-Biscoe, C.H. (1973) Intrauterine development after diapause in the marsupial Macropus eugenii. Devl Biol. 32, 28-40.

Renfree, M.B., Flint, A.P.F., Green, S.W. \& Heap, R.B. (1984) Ovarian steroid metabolism and luteal oestrogens in the tammar wallaby. J. Endocr. 101, 231-240.

Rodbard, D., Bridson, W. \& Rayford, P.L. (1969) Rapid calculation of radioimmunoassay results. J. Lab. clin. Med. 74, 770-781.

Scaramuzzi, R.J. \& Land, R.B. (1978) Oestradiol levels in sheep plasma during the oestrous cycle. J. Reprod. Fert. 53, 167-171.

Shaw, G. \& Renfree, M.B. (1984) Concentrations of oestradiol-17 $\beta$ in plasma and corpora lutea throughout pregnancy in the tammar, Macropus eugenii. $J$. Reprod. Fert. 72, 29-37.
Steel, R.G.D. \& Torrie, J.H. (1960) Principles and Procedures of Statistics with Special Reference to Biological Sciences. McGraw-Hill, New York.

Tyndale-Biscoe, C.H. \& Rodger, J.C. (1978) Differential transport of spermatozoa into the two sides of the genital tract of a monovular marsupial, the tammar wallaby (Macropus eugenii). J. Reprod. Fert. 52, 3743.

Tyndale-Biscoe, C.H., Hinds, L.A., Horn, C.A. \& Jenkin, G. (1983) Hormonal changes at oestrus, parturition and post-partum oestrus in the tammar wallaby (Macropus eugenii). J. Endocr. 96, 155-161.

Walker, M.T. \& Gemmell, R.T. (1983) Plasma concentrations of progesterone, oestradiol-17 $\beta$ and $13,14-$ dihydro-15-oxoprostaglandin $F_{2 \alpha}$ in the pregnant wallaby, Macropus rufogriseus rufogriseus. J. Endocr. 97, 369-377.

Young, I.R. \& Renfree, M.B. (1979) The effects of corpus luteum removal during gestation on parturition in the tammar wallaby (Macropus eugenii). J. Reprod. Fert. 56, 249-254.

Received 8 May 1984 